\title{
Faktor-Faktor Yang Mempengaruhi Manajemen Laba Pada Perusahaan Badan Usaha Milik Negara (BUMN) Yang Terdaftar Pada Bursa Efek Indonesia (BEI) Tahun 2017 - 2019
}

\author{
Pandu Wiratama1, Gideon Setyo Budiwitjaksono ${ }^{2}$ \\ UPN Veteran Jawa Timur ${ }^{1,2}$ \\ Email: pndwrtm@gmail.com
}

\begin{abstract}
The aim of this research is to provide empirical evidence the effect of firm size, leverage, profitability, Chief Executive Officer (CEO) educational background, and Chief Executive Officer (CEO) in the final year of his services on earnings management. The population in this study are State-Owned Enterprises (SOE) listed on the Indonesia Stock Exchange (IDX) 2017 - 2019. This research used 16 State-Owned Enterprises (SOE), selected using purposive sampling method. Data were analyzed using multiple regression. Based on the result of analysis concluded that all the independent variables, firm size, size, leverage, profitability, Chief Executive Officer (CEO) educational background, and Chief Executive Officer (CEO) in the final year of his services had no significant effect on earnings management.
\end{abstract}

Keywords: Earnings management, Firm size, Leverage, Profitability, CEO educational background, and CEO in the final year of his services

\section{Pendahuluan}

Laporan keuangan merupakan cerminan dari kondisi suatu perusahaan serta menjadi sarana komunikasi informasi keuangan kepada stakeholders. Informasi yang disajikan oleh perusahaan dalam laporan keuangan menjadi dasar pertimbangan para stakeholders dalam mengambil keputusan bisnisnya. Hal ini sejalan dengan apa yang dinyatakan dalam kerangka konseptual Financial Accounting Standards Board (FASB) bahwa tujuan laporan keuangan adalah untuk memberikan informasi yang berguna untuk keputusan bisnis.

Informasi laba merupakan hal yang paling menjadi perhatian pemakai terutama bagi Investor karena sebagai peningkatan kekayaan Investor atas hasil penanaman modalnya. Laba merupakan salah satu bagian penting dalam laporan keuangan serta sebagai parameter yang paling spesifik untuk mengukur kinerja perusahaan dan kinerja manajemen. Tuntutan perusahaan unuk mencapai target 
laba yang telah ditentukan dapat menjadi motivasi Manajer untuk melakukan Manajemen laba (Asitalia dan Trisnawati, 2017).

Kinerja keuangan atau laporan laba-rugi dan penghasilan komprehensif lain sebagai bagian dari laporan keuangan, sering menjadi target rekayasa melalui tindakan oportunis manajemen untuk memaksimumkan kepuasannya. Hal ini dapat merugikan pemegang saham atau Investor karena informasi laba yang disajikan dapat menyebabkan keputusan investasi yang salah. Tindakan oportunis tersebut dilakukan dengan cara memilih kebijakan akuntansi tertentu, sehingga laba perusahaan dapat diatur, dinaikkan atau diturunkan sesuai dengan keinginannya (Apriyani et al, 2019)

Perilaku manajemen untuk mengatur laba sesuai dengan keinginannya dikenal dengan istilah Manajemen laba. Manajemen laba merupakan suatu tindakan oportunistik yang dapat dilakukan oleh Manajer untuk memaksimalkan kepentingannya dalam menghadapi kontrak kompensasi, kontrak utang dan biaya politik, sehingga Manajer perusahaan lebih mengetahui informasi internal perusahaan dibandingkan dengan pemegang saham. Manajer (agent) perusahaan sebagai pengelola berkewajiban memberikan informasi yang benar kepada para pengguna laporan keuangan, tetapi informasi-informasi yang disampaikan terhadap para pengguna laporan keuangan terkadang tidak sesuai dengan kondisi yang sebenarnya (Minarsy et al, 2018).

Menurut Jensen dan Meckling (1976) Manajemen laba yang dilakukan perusahaan muncul karena adanya hubungan agensi antara pemegang saham (principal) dan Manajer (agent). Hubungan agensi antara pemegang saham dan manajemen tersebut dijelaskan dalam teori keagenan. Teori keagenan (agency theory) menjelaskan bahwa hubungan agensi muncul ketika satu orang atau lebih pemegang saham (principal) mempekerjakan orang lain (agent) untuk memberikan suatu jasa dan kemudian mendelegasikan wewenang pengambilan keputusan kepada agent tersebut. Prinsip utama teori ini menyatakan adanya hubungan kerja antara pihak yang memberi wewenang yaitu pemegang saham (principal) dengan pihak yang menerima wewenang yaitu Manajer (agent).

Fenomena praktek Manajemen laba banyak terjadi pada perusahaan- 
perusahaan besar di Indonesia, tidak terkecuali pada perusahaan Badan Usaha Milik Negara (BUMN) seperti kasus yang terjadi pada PT Garuda Indonesia (Persero) Tbk di tahun 2019, PT Timah (Persero) Tbk tahun 2015, PT waskita Karya (Persero) Tbk tahun 2009. PT Garuda Indonesia (Persero) Tbk menyajikan kembali (restatement) Laporan Keuangan tahun 2018 yang sudah direvisi menyusul hasil putusan Kementerian Keuangan, Otoritas Jasa Keuangan (OJK) dan Badan Pemeriksa Keuangan (BPK). Dalam penyajian kembali Laporan Keuangan tahun tersebut, PT Garuda Indonesia (Persero) Tbk mencatatkan rugi bersih sebesar US\$ 175,028 juta atau sekitar Rp 2,4 triliun (kurs Rp 14.000), laporan ini berbeda dari sajian sebelumnya, di mana dicatatkan laba sebesar US \$ 5,018 juta atau sebesar Rp 70 miliar.

Kasus penyajian kembali laporan keuangan PT PT Garuda Indonesia (Persero) Tbk terjadi pada kuartal I tahun 2019, dimana pada momen tersebut juga berlangsung pesta demokrasi Pemilihan Umum (PEMILU) serentak di Indonesia, sehingga ada kemungkinan akan terjadi pergantian kekuasaan atau pemerintah. Adanya pergantian kekuasaan atau pemerintah, maka ada kemungkinan terjadi pergantian direksi pada masing-masing perusahaan BUMN.

BUMN merupakan perusahaan yang kepemilikannya dikuasai oleh Negara, sehingga memiliki tingkat publisitas dan akuntabilitas yang tinggi. Indonesia merupakan Negara yang berdasarkan atas kedaulatan rakyat, sehingga dapat dikatakan penguasaan badan usaha oleh Negara sama artinya dengan penguasaan oleh rakyat, maka BUMN juga memiliki kewajiban untuk mempertanggungjawabkan aktivitasnya kepada rakyat. Adanya kewajiban tersebut secara otomatis menyebabkan tingginya sensitivitas atas segala aktivitas dan pelaporan perusahaan. Hal ini memicu tingkat kontrol yang tinggi pada perusahaan, terutama dalam aktivitas dan pelaporannya, sehingga penilaian atas tindakan Manajemen laba akan menjadi lebih ketat (Zain, 2015)

Berdasarkan latar belakang di atas maka rumusan masalah dalam penelitian ini adalah: Apakah ukuran perusahaan, leverage, profitabilitas, latar belakang pendidikan direktur utama, dan direktur utama yang akan mengakhiri masa jabatannya berpengaruh terhadap manajemen laba? 
Tujuan penelitian ini adalah untuk memperoleh bukti empiris pengaruh ukuran perusahaan, leverage, profitabilitas, latar belakang pendidikan direktur utama, dan direktur utama yang akan mengakhiri masa jabatannya berpengaruh terhadap manajemen laba

Hasil penelitian ini diharapkan mampu memberikan maanfaat bagi pihak perusahaan dalam menghindari terjadinya manajemen laba yang dapat merugikan stakeholders. Bagi investor, agar penelitian ini dapat menjadi bahan pertimbangan dan masukan dalam pengambilan keputusan investasi di masa depan.

\section{Tinjauan Pustaka}

\subsection{Landasan Teori}

\subsubsection{Agency Theory}

Jensen dan Meckling (1976) mendefinisikan agency theory sebagai suatu bentuk hubungan kontraktual antara seseorang (beberapa orang) yang bertindak sebagai pemegang saham (principal) dan seseorang (beberapa orang) lainnya yang bertindak sebagai Manajer (agent), untuk melakukan pelayanan bagi kepentingan principal dan mencakup pendelegasian wewenang dalam pembuatan keputusan dari principal kepada agent.

Menurut definisi di atas dapat dikatakan bahwa agent dan principal memiliki hubungan kontrak. Agen berkewajiban untuk melakukan tugas dan kepentingan principal, hal ini mendorong adanya teori keagenan dimana keduanya akan sama-sama memaksimalkan kepentingannya. Agency theory memiliki asumsi bahwa masing-masing individu semata-mata termotivasi oleh kepentingan dirinya sendiri sehingga menimbulkan konflik kepentingan antara principal dan agent. Agent akan termotivasi untuk memaksimalkan fee kontraktual yang diterimanya dan principal berusaha untuk memaksimalkan return atas penggunaan sumber dayanya. Terjadinya konflik kepentingan antara principal dan agent karena kemungkinan agent bertindak tidak sesuai dengan kepentingan principal.

Eisenhardt (1989) dalam Agustia (2013) menggunakan tiga asumsi sifat dasar manusia guna menjelaskan tentang teori agensi yaitu (1) manusia pada umumnya mementingkan diri sendiri (self interest); (2) manusia memiliki daya pikir terbatas mengenai persepsi masa mendatang (bounded rationality); dan (3) 
manusia selalu menghindari resiko (risk averse). Berdasarkan asumsi sifat dasar manusia tersebut agen atau manajemen sebagai manusia kemungkinan besar akan bertindak berdasarkan sifat opportunistic, yaitu mengutamakan kepentingan pribadinya.

\subsubsection{Positive Accounting Theory}

Menurut Watts dan Zimmerman (1990) dalam Positive Accounting Theory: A Ten Year Perspective terdapat tiga hipotesis yang memotivasi agen atau manajemen melakukan tindakan Manajemen laba, yaitu:

\section{Bonus Plan Hypothesis}

Terdapat kecenderungan bagi manajemen untuk menggunakan metode-metode akuntansi yang meningkatkan laba apabila perusahaan menetapkan skema kompensasi bonus yang didasarkan pada profit.

\section{Debt Equity Hypothesis}

Terdapat kecenderungan bahwa semakin tinggi rasio utang atau ekuitas suatu perusahaan yang ekuivalen dengan semakin dekatnya perusahaan terhadap kendala-kendala dalam perjanjian dan terjadinya cost kemacetan teknis, maka semakin mungkin Manager untuk menggunakan metode-metode akuntansi yang meningkatkan laba.

\section{Political Cost Hypothesis}

Perusahaan besar lebih cenderung menggunakan metode akuntansi yang mengurangi laba yang dilaporkan daripada perusahaan kecil.

\subsubsection{Manajemen laba}

Menurut Healy dan Wahlen (1999) menyatakan bahwa Manajemen laba terjadi ketika manajemen menggunakan keputusan tertentu dalam pelaporan keuangan dan penyusunan transaksi-transaksi yang mengubah laporan keuangan. Hal ini bertujuan untuk menyesatkan para pengguna laporan keuangan tentang kondisi kinerja ekonomi perusahaan, serta untuk mempengaruhi penghasilan kontraktual yang mengendalikan angka akuntansi yang dilaporkan.

Menurut Schipper (1989) dalam Gunawan et al (2015), Manajemen laba adalah suatu kondisi dimana manajemen melakukan intervensi dalam proses penyusunan laporan keuangan bagi pihak eksternal sehingga dapat meratakan, 
menaikkan, dan menurunkan laba. Manajemen laba menurut Scott (2011) merupakan keputusan dari Manajer untuk memilih kebijakan akuntansi tertentu yang dianggap bisa mencapai tujuan yang diinginkan.

Pola Manajemen laba menurut Scott (2011) dapat dilakukan dengan cara taking a bath, laba minimazation, laba maximization, laba smoothing, offsetting extraordinary atau unusual gains, aggresive accounting applications, dan timing revenue dan expense recognition. Teknik untuk merekayasa laba menurut Setiawati dan Na'im (2000) dapat dikelompokkan menjadi 3 kelompok, yaitu memanfaatkan peluang untuk membuat estimasi akuntansi, merubah metode akuntansi, dan menggeser periode biaya atau pendapatan.

\subsubsection{Ukuran Perusahaan}

Ukuran perusahaan merupakan suatu skala dimana suatu perusahaan dapat diklasifikasikan besar atau kecilnya menurut berbagai cara antara lain dengan log size, total aktiva, nilai pasar saham dan lain-lain. Besar kecilnya suatu perusahaan akan mempengaruhi kemampuan dalam menanggung risiko yang mungkin timbul dari berbagai situasi yang dihadapi oleh perusahaan. Perusahaan besar mempunyai risiko yang lebih rendah dari perusahaan kecil. Hal ini karena kondisi pasar perusahaan besar mempunyai kontrol yang lebih baik, sehingga mereka mampu bersaing dalam pasar. Selain itu perusahaan besar memiliki sumber daya yang lebih banyak untuk meningkatkan nilai perusahaan karena memiliki akses yang baik terhadap sumber informasi eksternal dibandingkan dengan perusahaan kecil (Zakia et al, 2019).

Menurut Murhadi (2013) Firm Size diukur dengan mentrasformasikan total aset yang dimiliki perusahaan ke dalam bentuk logaritma natural. Ukuran perusahaan diproksikan dengan menggunakan Log Natural Total Aset dengan tujuan agar mengurangi fluktuasi data yang berlebih. Dengan menggunakan log natural, jumlah aset dengan nilai ratusan miliar bahkan triliun akan disederhanakan, tanpa mengubah proporsi dari jumlah aset yang sesungguhnya.

"Ukuran perusahaan = Ln (Total Aset)"

\subsubsection{Leverage}

Menurut Kasmir (2016) leverage adalah rasio yang digunakan untuk 
mengukur sejauh mana aktiva perusahaan dibiayai dengan utang. Artinya berapa besar beban utang yang ditanggung perusahaan dibandingkan dengan aktivanya. Dalam arti luas dikatakan bahwa rasio leverage digunakan untuk mengukur kemampuan perusahaan untuk membayar seluruh kewajibannya, baik jangka pendek maupun jangka panjang apabila perusahaan dibubarkan (dilikuidasi). Dalam praktiknya, terdapat beberapa jenis leverage ratio yang sering digunakan perusahaan. Adapun jenis-jenis rasio yang ada dalam leverage ratio menurut Kasmir antara lain:

1. Debt to Asset Ratio (Debt Ratio) merupakan rasio utang yang digunakan untuk mengukur perbandingan antara total utang dengan total aktiva. Dengan kata lain, seberapa besar aktiva perusahaan dibiayai oleh utang atau seberapa besar utang perusahaan berpengaruh terhadap pengelolaan aktiva. Rumusan untuk mencari debt ratio dapat digunakan sebagai berikut:

$$
\text { Debt to Asset Ratio }=\frac{\text { Total Debt }}{\text { Total Assets }}
$$

2. Debt to Equity Ratio (DER) merupakan rasio yang digunakan untuk menilai utang dengan ekuitas. Rasio ini dicari dengan cara membandingkan antara seluruh utang, termasuk utang lancar dengan seluruh ekuitas. Rasio ini berguna untuk mengetahui jumlah dana yang disediakan peminjam (kreditor) dengan pemegang saham perusahaan. Dengan kata lain, rasio ini berfungsi untuk mengetahui setiap rupiah modal sendiri yang dijadikan untuk jaminan utang. Rumus untuk mencari debt to equity ratio dapat digunakan perbandingan antara total utang dengan total ekuitas sebagai berikut:

$$
\text { Debt to Equity Ratio }=\frac{\text { Total Utang (Debt) }}{\text { Ekuitas (Equity) }}
$$

3. Long Term Debt to Equity Ratio (LTDtER) merupakan rasio antara utang jangka panjang dengan modal sendiri. Tujuannya adalah untuk mengukur berapa bagian dari setiap rupiah modal sendiri yang dijadikan jaminan utang jangka panjang dengan cara membandingkan antara utang jangka panjang dengan modal sendiri yang disediakan oleh perusahaan. Rumusan untuk 
mencari long term debt to equity ratio adalah dengan menggunakan perbandingan antara utang jangka panjang dengan modal sendiri, yaitu:

$$
\text { Long Term Debt to Equity Ratio }=\frac{\text { Utang jangka panjang }(\text { Debt })}{\text { Ekuitas }(\text { Equity })}
$$

4. Times interest earned merupakan rasio untuk mengukur sejauh mana pendapatan dapat menurun tanpa membuat perusahaan merasa malu karena tidak mampu membayar biaya bunga tahunannya. Rumus untuk mencari time interest earned dapat digunakan dengan dua cara sebagai berikut:

$$
\begin{aligned}
& \text { Times Interest Earned Ratio }=\frac{\text { Earning Before Interest and Tax }}{\text { Interest }} \\
& \text { Times Interest Earned Ratio }=\frac{\text { Earning Before Tax }(\mathrm{EBT})+\text { Interest }}{\text { Interest }}
\end{aligned}
$$

5. Fixed Charge Coverage merupakan rasio yang menyerupai time interest earned ratio. Hanya saja perbedaannya adalah rasio ini dilakukan apabila perusahaan memperoleh utang jangka panjang atau menyewa aktiva berdasarkan kontrak sewa (lease contract). Rumusan untuk mencari fixed charge coverage adalah sebagai berikut:

Fixed Charge Coverage $=\frac{\text { Earning Before Interest \& Tax }(\mathrm{EBIT})+\text { leasse }}{(\text { Interest })+\text { leasse }}$

\subsubsection{Profitabilitas}

Menurut Kasmir (2016), bahwa: "rasio profitabilitas merupakan rasio yang digunakan untuk menilai kemampuan perusahaan dalam mencari keuntungan". Rasio ini juga memberikan ukuran tingkat efektivitas manajemen suatu perusahaan. Hal ini ditunjukkan oleh laba yang dihasilkan dari penjualan dan pendapatan investasi. Intinya adalah penggunaan rasio ini menunjukkan efisiensi perusahaan. Jenis-jenis rasio profitabilitas menurut Kasmir:

1. Ratio Profit Margin atau Profit Margin on Sales merupakan salah satu rasio yang digunakan untuk mengukur margin laba atas penjualan. Terdapat dua rumus untuk mencari Ratio Profit Margin atau Profit Margin on Sales, yaitu sebagai berikut: 
a. Untuk margin laba kotor dengan rumus:

Profit Margin on Sales $=\frac{\text { Sales }(\text { Penjualan })-\text { COGS }}{\text { Sales }(\text { Penjualan })}$

b. Untuk margin laba bersih dengan rumus:

Profit Margin on Sales $=\frac{\text { Earning After Interest and Tax }(\text { EAIT })}{\text { Sales }(\text { Penjualan })}$

2. Hasil Pengembalian Investasi atau Return On Investment (ROI) merupakan rasio yang menunjukkan hasil (return) atas jumlah aktiva yang digunakan dalam perusahaan. ROI juga merupakan suatu ukuran tentang efektivitas manajemen dalam mengelola investasinya. Rumus untuk mencari hasil pengembalian investasi atau return on investment (ROI) sebagai berikut:

$$
\text { Return on Investment }=\frac{\text { Earning After } \text { Interest and } \text { Tax }(\text { EAIT })}{\text { Total Assets }}
$$

3. Hasil Pengembalian Ekuitas atau Return On Equity (ROE) merupakan rasio untuk mengukur laba bersih sesudah pajak dengan modal sendiri. Rasio ini menunjukkan efisiensi penggunaan modal sendiri. Semakin tingggi rasio ini, semakin baik. Artinya, posisi pemegang saham perusahaan semakin kuat, demikian pula sebaliknya. Rumus untuk mencari Hasil Pengembalian Ekuitas atau Return On Equity (ROE) dapat digunakan sebagai berikut:

$$
\text { Return on Equity }(\text { ROE })=\frac{\text { Earning After Interest and Tax }(\text { EAIT })}{\text { Equity }}
$$

\subsection{Hipotesis penelitian}

\subsubsection{Pengaruh Ukuran Perusahaan Terhadap Manajemen laba}

Berdasarkan political cost hypothesis yang dipaparkan oleh Watt dan Zimmerman (1990) berasumsi bahwa perusahaan besar lebih cenderung menggunakan metode akuntansi yang mengurangi laba yang dilaporkan daripada perusahaan kecil. Political cost hypothesis Watt dan Zimmerman dibuktikan oleh penelitian Ayem dan Arifah (2019), Zakia et al (2019), Nalarreason et al (2019), Purnama (2017), Astari dan Suryanawa (2017), Sihaloho dan Sitanggang (2016), Amelia dan Hernawati (2016), yang menyatakan ukuran perusahaan berpengaruh positif terhadap Manajemen laba. Tujuan dari adanya Manajemen laba ini untuk 
menghindari biaya politis, semakin besar ukuran sebuah perusahaan, maka biaya politis yang dikeluarkan juga akan semakin besar sejalan dengan ketatnya regulasi pemerintah dalam hal laba. Praktik Manajemen laba dijalankan dengan cara memindahkan laba periode saat ini ke periode selanjutnya, maka laba periode saat ini tidak terlalu tinggi.

Penelitian Arthawan dan Wirasedana (2018), Santi dan Wardani (2018), Rice (2016), Ulya dan Khairunnisa (2015) yang menyatakan ukuran perusahaan berpengaruh negatif terhadap Manajemen laba. Hal ini menunjukkan semakin kecil ukuran perusahaan maka semakin besar perusahaan melakukan praktik Manajemen laba. Hal tersebut dapat terjadi karena adanya indikasi manajemen tidak mampu melakukan penjualan secara efektif sehingga manajemen cenderung melakukan praktik income smoothing.

Berdasarkan penelitian diatas yang memberikan hasil penelitian yang tidak konsisiten, maka diajukan hipotesis sebagai berikut :

H1 : Ukuran perusahaan berpengaruh positif terhadap Manajemen laba.

\subsubsection{Pengaruh Leverage Terhadap Manajemen laba}

Berdasarkan debt equity hypothesis yang dipaparkan oleh Watt dan Zimmerman (1990) berasumsi bahwa semakin tinggi rasio utang atau ekuitas suatu perusahaan yang ekuivalen dengan semakin dekatnya perusahaan terhadap kendalakendala dalam perjanjian dan terjadinya cost kemacetan teknis, semakin mungkin Manager untuk menggunakan metode-metode akuntansi yang meningkatkan laba. Debt equity hypothesis Watt dan Zimmerman dibuktikan oleh penelitian Apriyani et al (2019), Fandriani dan Tunjung (2019), Nalarreason et al (2019), Agustia dan Suryani (2018), Minarsy et al (2018), Astari dan Suryanawa (2017), Wardani dan Isbela (2017), Sihaloho dan Sitanggang (2016), Wiasa Putri dan Widanaputra (2015), Agustia (2013), Napitupulu (2012) menyatakan leverage mempunyai pengaruh positif terhadap Manajemen laba. Perusahaan dengan tingkat leverage yang tinggi akibat besarnya total hutang terhadap total aktiva akan menghadapi resiko default yang tinggi yaitu perusahaan terancam tidak mampu memenuhi kewajibannya. Tindakan Manajemen laba dapat dijadikan sebagai mekanisme untuk menghindarkan default tersebut. Pemenuhan kewajiban harus tetap dilakukan 
dan dapat dihindarkan dengan Manajemen laba.

Penelitian Prihartono (2018), Asitalia dan Trisnawati (2017), Rice (2016), Noviyanti (2014), Sari dan Asyik (2013) menyatakan bahwa leverage berpengaruh negatif terhadap Manajemen laba, hal ini dapat diartikan bahwa semakin besar leverage perusahaan, kemungkinan terjadinya praktik Manajemen laba kecil, begitu juga sebaliknya. Hal ini dapat membuktikan bahwa manajemen perusahaan selaku agen perusahaan telah bekerja dengan semestinya, melaporkan tentang kinerja perusahaan sesuai dengan keadaan sebenarnya kepada pemegang saham perusahaan.

Berdasarkan penelitian diatas yang memberikan hasil penelitian yang tidak konsisiten, maka diajukan hipotesis sebagai berikut :

$\mathrm{H} 2$ : Leverage berpengaruh positif terhadap Manajemen laba.

\subsubsection{Pengaruh Profitabilitas Terhadap Manajemen laba}

Berdasarkan bonus plan hypothesis yang dipaparkan oleh Watt dan Zimmerman (1990) berasumsi bahwa terdapat kecenderungan bagi manajemen untuk menggunakan metode-metode akuntansi yang meningkatkan laba apabila perusahaan menetapkan skema kompensasi bonus yang didasarkan pada profit. Bonus plan hypothesis Watt dan Zimmerman dibuktikan oleh penelitian Zakia et al (2019), Astari dan Suryanawa (2017), Ulya dan Khairunnisa (2015), Noviyanti (2014), Napitupulu (2012) menyatakan bahwa profitabilitas berpengaruh positif terhadap Manajemen laba, hal ini menunjukkan bahwa semakin tinggi profitabilitas maka semakin tinggi Manajemen laba.

Penelitian Fandriani dan Tunjung (2019), Agustia dan Suryani (2018), Wardani dan Isbela (2017), Amelia dan Hernawati (2016), Yusrilandari et al (2016), Wiyadi et al (2015), dan Gunawan et al (2015) menyatakan hasil yang berbeda, bahwa variabel profitabilitas tidak berpengaruh terhadap Manajemen laba. Hal ini menunjukan bahwa semakin tinggi atau rendahnya profitabilitas yang diperoleh oleh suatu perusahaan tidak akan mempengaruhi tingkat Manajemen laba perusahaan. Profitabilitas yang semakin meningkat menunjukkan kinerja perusahaan yang baik dan para pemegang saham akan menerima keuntungan yang semakin meningkat, selain itu Manajer juga mendapatkan keuntungan sehingga dia 
tidak akan melakukan tindakan Manajemen laba

Berdasarkan penelitian diatas yang memberikan hasil penelitian yang tidak konsisiten, maka diajukan hipotesis sebagai berikut :

H3 : Profitabilitas berpengaruh positif terhadap Manajemen laba.

\subsubsection{Pengaruh Latar Belakang Pendidikan Direktur Utama Terhadap Manajemen laba}

Berdasarkan Agency theory yang dipaparkan oleh Jensen dan Meckling (1976) adanya konflik kepentingan antara pemegang saham (principal) dan Manajer (agent) karena kemungkinan agen bertindak tidak sesuai dengan kepentingan principal. Agent sebagai manusia kemungkinan besar akan bertindak berdasarkan sifat opportunistic, yaitu mengutamakan kepentingan pribadinya. Agent atau direktur utama dengan Latar belakang pendidikan akuntansi dan keuangan lebih berpotensi melakukan tindakan Manajemen laba untuk kepentingan pribadinya.

Chiang et al (2016) menyatakan bahwa Chairman Of the Boards (COBs) dengan latar belakang pendidikan manajemen dan keuangan berpengaruh signifikan negatif terhadap Manajemen laba, Chairman Of the Boards (COBs) dengan latar belakang pendidikan akuntansi berpengaruh signifikan positif terhadap Manajemen laba. Penelitian Gounopoulos dan Pham, (2018) menyatakan hasil yang berbeda, bahwa direktur utama yang memiliki keahlian dalam bidang akuntansi dan keuangan berpengaruh signifikan negatif terhadap menajamen laba. Hal ini menunjukan bahwa direktur utama yang memiliki keahlian dalam bidang akuntansi dan keuangan akan lebih berhati-hati (konservatis) dalam membuat laporan laba perusahaan agar cenderung stabil sehingga akan menarik Investor.

Berdasarkan penelitian diatas yang memberikan hasil penelitian yang tidak konsisiten, maka diajukan hipotesis sebagai berikut :

H4 : Latar belakang pendidikan direktur utama berpengaruh positif terhadap Manajemen laba.

\subsubsection{Pengaruh Direktur Utama yang Akan Mengakhiri Masa Jabatannya Terhadap Manajemen laba}

Berdasarkan Agency theory yang dipaparkan oleh Jensen dan Meckling 
(1976) adanya konflik kepentingan antara pemegang saham (principal) dan Manajer (agent) karena kemungkinan agen bertindak tidak sesuai dengan kepentingan principal. Agent sebagai manusia kemungkinan besar akan bertindak berdasarkan sifat opportunistic, yaitu mengutamakan kepentingan pribadinya. Agent atau direktur utama yang akan mengakhiri masa jabatannya di suatu perusahaan memiliki dorongan untuk memanipulasi laba guna memperoleh bonus yang lebih tinggi di masa akhir jabatannya.

Penelitian Ali dan Zhang (2015), Patni dan Sujana (2016), Dewi dan Rasmini (2018) menyatakan bahwa direktur utama yang akan mengakhiri masa jabatannya di suatu perusahaan berpengaruh positif terhadap Manajemen laba. Hal ini menunjukan bahwa direktur utama yang akan mengakhiri masa jabatannya di suatu perusahaan memiliki dorongan untuk memanipulasi laba guna memperoleh bonus yang lebih tinggi di masa akhir jabatannya. Direktur utama juga akan ingin menunjukkan kinerja terbaiknya dengan harapan akan menaikan reputasi dan citra mereka, sehingga meningkatkan kemungkinan direktur utama tersebut dipilih kembali untuk periode jabatan selanjutnya.

Penelitian Vernando dan Rakhman (2018) menyatakan hasil yang berbeda, bahwa direktur utama yang akan mengakhiri masa jabatannya tidak berpegaruh terhadap Manajemen laba, hal ini dikarenakan direktur utama tidak memiliki cukup waktu untuk mengurangi pengeluaran diskresioner untuk meningkatkan laba. Direktur utama akan memiliki cukup waktu untuk melakukan Manajemen laba jika direktur utama tersebut mengetahui kapan masa jabatannya berakhir atau pension. H5 : Direktur utama yang akan mengakhiri masa jabatannya berpengaruh positif terhadap Manajemen laba.

\section{Metode Penelitian}

\subsection{Populasi dan Sampel}

Populasi yang digunakan sebagai obyek dalam penelitian ini adalah laporan keuangan tahunan audited perusahaan Badan Usaha Milik Negara (BUMN) yang terdaftar pada Bursa Efek Indonesia (BEI) tahun 2017- 2019. Berdasarkan informasi pada situs resmi Bursa Efek Indonesia (www.idx.co.id), terdapat 20 perusahaan BUMN yang terdaftar pada Bursa Efek Indonesia (BEI) tahun 2017- 
2019, sehingga populasi dalam penelitian ini adalah sebanyak 60 laporan keuangan tahunan audited perusahaan BUMN. Pemilihan sampel dilakukan dengan metode purposive sampling dan diperoleh 16 perusahaan BUMN yang terdaftar pada BEI. Periode pengamatan berlangsung mulai tahun 2017 sampai dengan 2019, sehingga diperoleh 48 sampel penelitian.

\subsection{Definisi Operasional dan Pengukuran Variabel}

\subsubsection{Ukuran Perusahaan (FIRMSIZE) Sebagai Variabel Independen $\left(\mathrm{X}_{1}\right)$}

Firm Size diukur dengan mentrasformasikan total aset yang dimiliki perusahaan ke dalam bentuk logaritma natural. Dalam penelitian ini ukuran perusahaan diukur dengan menggunakan skala pengukuran rasio Log Natural Total Aset dengan dengan tujuan agar mengurangi fluktuasi data yang berlebih.

$$
\text { "FIRMSIZE = Ln (Total Asset }) "
$$

\subsubsection{Leverage (LEV) Sebagai Variabel Independen $\left(\mathrm{X}_{2}\right)$}

Leverage adalah rasio yang digunakan untuk mengukur sejauh mana aktiva perusahaan dibiayai dengan utang. Penelitian ini mengukur variabel leverage dengan menggunakan debt ratio dengan skala pengukuran rasio dan satuan persen (\%). Debt Ratio merupakan rasio utang yang digunakan untuk mengukur perbandingan antara total utang dengan total aktiva. Rumusan untuk mencari debt ratio dapat digunakan sebagai berikut:

$$
L E V=\frac{\text { Total debt }}{\text { Total Asset }} \times 100 \%
$$

\subsubsection{Profitabilitas (PROFIT) Sebagai Variabel Independen ( $\left.\mathrm{X}_{3}\right)$}

Profitabilitas merupakan rasio yang digunakan untuk menilai kemampuan perusahaan dalam mencari keuntungan. Rasio ini juga memberikan ukuran tingkat efektivitas manajemen suatu perusahaan. Penelitian ini mengukur variabel profitabilitas dengan menggunakan rasio return on Assets (ROA) dengan skala pengukuran rasio dan satuan persen (\%) dengan rumus:

$$
\text { PROFIT }=\frac{\text { Earning After Interest and Tax }(E A I T)}{\text { Total Assets }} \times 100 \%
$$

\subsubsection{Latar Belakang Pendidikan Direktur Utama Sebagai Variabel Independen $\left(\mathrm{X}_{4}\right)$}

Variabel latar belakang pendidikan direktur utama dalam penelitian ini 
menggunakan variabel dummy, dimana skala pengukuran datanya menggunakan skala nominal dengan kriteria diberi skor 1 untuk direktur utama dengan latar belakang pendidikan akuntansi dan keuangan, serta skor 0 untuk direktur utama dengan latar belakang pendidikan selain akuntansi dan keuangan.

\subsubsection{Direktur utama (CEO) yang akan mengakhiri masa jabatannya Sebagai Variabel Independen $\left(\mathrm{X}_{5}\right)$}

Variabel direktur utama yang akan mengakhiri masa jabatannya dalam penelitian ini menggunakan variabel dummy, dimana skala pengukuran datanya menggunakan skala nominal dengan kriteria diberi skor 1 untuk direktur utama yang akan mengakhiri masa jabatannya, serta skor 0 untuk direktur utama yang tidak mengakhiri masa jabatannya.

\subsubsection{Manajemen Laba sebagai Variabel Dependen (Y)}

Penelitian ini menggunakan Modified Jones Model (Dechow et al, 1995) untuk mendapatkan nilai discretionary accruals yang merupakan proksi praktik Manajemen laba dengan skala pengukuran rasio. Untuk menghitung discretionary accruals (DA), maka terlebih dahulu dihitung total akrual dengan rumus :

$$
T A C_{i t}=N I_{i t}-C F O_{i t}
$$

Dimana

$\mathrm{TAC}_{\mathrm{it}}=$ Total accrual pada perusahaan i pada periode $\mathrm{t}$;

$\mathrm{NI}_{\mathrm{it}} \quad=$ laba bersih pada perusahaan $\mathrm{i}$ pada periodet $\mathrm{t}$;

$\mathrm{CFO}_{i \mathrm{t}}=$ Arus kas dari kegiatan operasi perusahaan i pada periode $\mathrm{t}$.

Kemudian menghitung nilai akrual dengan persamaan regresi menggunakan regresi linier berganda sebagai berikut:

$$
\left(\frac{T A C t}{A t-1}\right)=\propto_{1}\left(\frac{1}{A t-1}\right)+\propto_{2}\left(\frac{\Delta R E V t}{A t-1}\right)+\propto_{3}\left(\frac{P P E t}{A t-1}\right)+e
$$

Dimana:

TACt = Total accrual perusahaan pada tahun $\mathrm{t}$;

At-1 = Total asset perusahaan pada tahun $\mathrm{t}-1$;

$\Delta \mathrm{REVt}=$ Perubahan pendapatan perusahaan $\mathrm{i}$ dari tahun $\mathrm{t}-1$ ke tahun $\mathrm{t}$;

PPEt = Aset tetap perusahaan i pada tahun $\mathrm{t}$;

e $\quad=$ koefisien error. 
Kemudian untuk menghitung nilai non discretionary accrual dengan memasukkan nilai koefisien yang telah didapat dari hasil regresi, dengan rumus berikut ini :

$$
N D A t=\propto_{1}\left(\frac{1}{A t-1}\right)+\propto_{2}\left(\frac{\Delta R E V t-\Delta R E C t}{A t-1}\right)+\propto_{3}\left(\frac{P P E t}{A t-1}\right)
$$

Dimana:

NDAt = non discretionary accrual perusahaan i pada tahun t;

At-1 = Total asset perusahaan pada tahun $\mathrm{t}-1$;

$\triangle \mathrm{RECt}=$ Perubahan piutang perusahaan $\mathrm{i}$ dari tahun $\mathrm{t}-1$ ke tahun $\mathrm{t}$;

PPEt = Aset tetap perusahaan i pada tahun $\mathrm{t}$.

Kemudian berdasarkan persamaan-persamaan di atas, nilai discretionary accruals (DA) dihitung dengan dengan rumus :

$$
D A_{t}=\left(\frac{T A C_{t}}{A_{t-1}}\right)-N D A_{t}
$$

\subsection{Metode Analisis Data}

Teknik analisis yang digunakan dalam penelitian adalah analisis regresi linier berganda. Model regresi linear berganda ditunjukkan dalam persamaan sebagai berikut :

$\mathrm{Y}=\alpha+\beta_{1} \mathrm{X}_{1}+\beta_{2} \mathrm{X}_{2}+\beta_{3} \mathrm{X}_{3}+\beta_{4} \mathrm{X}_{4}+\beta_{5} . \mathrm{X}_{5}+\mathrm{e}$

Keterangan :

$\mathrm{Y} \quad=$ Manajemen laba

$\mathrm{X}_{\mathbf{1}} \quad=$ Ukuran perusahaan

$\mathrm{X}_{2}=$ Leverage

$\mathrm{X}_{3} \quad=$ Profitabilitas

$\mathrm{X}_{4} \quad=$ Latar belakang pendidikan direktur utama

$\mathrm{X}_{5} \quad=$ Direktur utama yang akan mengakhiri masa jabatannya

$\alpha \quad=$ Konstanta

$\beta=$ Koefisien regresi variabel independen

$\varepsilon \quad=$ term of error (tingkat kelonggaran kesalahan)

\section{Hasil Dan Pembahasan}

\subsection{Hasil Uji Normalitas Data dan Asumsi Klasik}


Uji normalitas dilakukan dengan uji statistik non-parametrik KolmogorovSmirnov. Data dikatakan normal jika nilai signifikan lebih besar dari 0,05. Hasil pengujian statistik Kolmogorov Smirnov menunjukkan bahwa data telah terdistribusi secara normal. Hal ini ditunjukkan oleh nilai signifikansi KolmogorovSmirnov yang berada di atas 0.05 yaitu sebesar 0.200 .

Pengujian terhadap adanya mulkolinieritas dalam penelitian ini adalah dengan menggunakan nilai tolerance dan variance inflation factor (VIF) pada model regresi. Jika tolerance value lebih dari 0,10 dan VIF kurang dari 10, hal ini menunjukkan bahwa tidak terjadi multikolienaritas. Hasil pengujian statistik menunjukkan variabel bebas atau independen dalam penelitian ini lebih kecil dari 10, artinya seluruh variabel bebas pada penelitian ini tidak terjadi gejala multikolinieritas.

Penelitian ini menggunakan Run Test untuk mendeteksi ada tidaknya autokorelasi. Dasar pengambilan keputusan uji statistik dengan Run test adalah jika nilai Asymp. Sig. (2-tailed) kurang dari 0,05, hal ini berarti data residual terjadi secara tidak random (sistematis), namun jika nilai Asymp. Sig. (2-tailed) lebih dari 0,05, hal ini berarti data residual terjadi secara random (acak). Hasil Pengujian statistik menunjukkan bahwa nilai test adalah -0.00017 dengan nilai signifikan 1.000 pada tingkat signifikan $5 \%$ atau 0.05 yang berarti bahwa residual random (acak) atau tidak terjadi autokorelasi.

Penelitian ini menggunakan grafik sccatterplot untuk mengetahui ada tidaknya heteroskedastisitas dalam suatu model regresi linier berganda. Jika tidak ada pola tertentu dan tidak menyebar di atas dan di bawah angka nol pada sumbu Y, maka tidak terjadi heteroskedastisitas. Hasil uji heteroskesdastisitas menunjukkan bahwa data terlihat tidak memiliki pola yang jelas, serta titik-titik menyebar di atas dan di bawah angka nol pada sumbu Y, dengan ini dapat disimpulkan bahwa tidak terjadi heteroskedastisitas.

\subsection{Hasil Analisis Regresi}

Berdasarkan hasil uji analisis regresi linier berganda dengan alat bantu komputer yang menggunakan Program SPSS Ver.23, dapat dilihat pada tabel berikut ini: 
Tabel 1: Hasil Analisis Regresi Linier Berganda dan Uji t

\begin{tabular}{lcrrrc}
\hline & $\begin{array}{c}\text { Unstandardized } \\
\text { Model }\end{array}$ & \multicolumn{3}{c}{$\begin{array}{c}\text { Standardized } \\
\text { Coefficients }\end{array}$} & \multicolumn{3}{c}{$\begin{array}{r}\text { Coefficients } \\
\end{array}$} & B & Std. Error & Beta & t & Sig. \\
\hline (Constant) & $-0,15963$ & 0,235 & & $-0,681$ & 0,50 \\
FIRMSIZE & 0,00411 & 0,008 & 0,101 & 0,501 & 0,62 \\
LEVERAGE & 0,00016 & 0,001 & 0,044 & 0,206 & 0,84 \\
PROFIT & 0,00953 & 0,006 & 0,256 & 1,497 & 0,14 \\
CEO & 0,03387 & 0,019 & 0,294 & 1,814 & 0,08 \\
ENDED & - & 0,020 & $-0,112$ & $-0,725$ & 0,47 \\
& 0,01446 & & & & \\
\hline
\end{tabular}

Sumber: data diolah penulis

Berdasarkan pada diatas dapat dibuat model persamaan regresi sebagai berikut:

$$
Y=-0,15963+0,00411 X_{1}+0,00016 X_{2}+0,00953 X_{3}+0,03387 X_{4}-0,01446 X_{5}
$$

\subsection{Hasil Uji t}

\subsubsection{Pengaruh Ukuran Perusahaan $\left(X_{1}\right)$ Terhadap Manajemen Laba (Y)}

Berdasarkan tabel 1 menunjukan besarnya t hitung sebesar 0.501, dengan tingkat signifikansi sebesar 0.620 (> 0.05) maka $\mathrm{H}_{0}$ diterima $\mathrm{H}_{\mathrm{i}}$ ditolak yang berarti ukuran perusahaan tidak berpengaruh signifikan terhadap Manajemen laba. Hal ini membuktikan bahwa ukuran perusahaan BUMN yang terdaftar dalam Bursa Efek Indonesia tidak mempengaruhi terjadinya praktik Manajemen laba. Perusahaan BUMN yang terdaftar dalam Bursa Efek Indonesia yang menjadi objek penelitian merupakan perusahaan terbuka yang mengharuskan memberikan keterbukaan informasi keuangan serta merupakan perusahaan yang sebagian besar kepemilikannya dikuasai oleh Negara, sehingga memiliki tingkat publisitas dan akuntabilitas yang tinggi. Hal ini memicu tingkat kontrol yang tinggi pada perusahaan, disamping itu ketatnya pengawasan dari internal perusahaan melalui komite audit dan komisaris independen serta kementerian BUMN dan pengawasan eksternal baik dari Otoritas Jasa Keuangan (OJK) serta para stakeholder sehingga memperkecil kemungkinan terjadinya Manajemen laba yang dilakukan oleh Manajer (agent). 
Hasil penelitian ini sejalan dengan penelitian yang dilakukan oleh Riska Astari dan Suputra (2019), Fandriani dan Tunjung (2019), Agustia dan Suryani (2018), Minarsy et al (2018), Prihartono (2018), Susanto dan Majid (2017), Wardani dan Isbela (2017), Yusrilandari et al (2016), Mariana et al, (2016), Veronica (2015), Gunawan et al (2015), Wiyadi et al (2015), Larasati (2015) yang dalam penelitiannya menunjukkan bahwa ukuran perusahaan tidak berpengaruh signifikan pada Manajemen laba. Hal ini dikarenakan Investor ataupun Kreditor tidak menjadikan besaran perusahaan yang dilihat berdasarkan total aset sebagai pertimbangan untuk menentukan keputusan investasi dan analisis kredit. Besarnya aset yang dimiliki suatu perusahaan tidak menjamin baik atau tidaknya performa perusahaan, sehingga perusahaan yang memiliki aset yang besar belum tentu memiliki kecenderungan untuk melakukan praktik Manajemen laba.

Hasil penelitian ini berbeda dengan political cost hypothesis yang dipaparkan oleh Watt dan Zimmerman (1990) berasumsi bahwa perusahaan besar lebih cenderung menggunakan metode akuntansi yang mengurangi laba yang dilaporkan daripada perusahaan kecil. Political cost hypothesis Watt dan Zimmerman dibuktikan oleh penelitian Ayem dan Arifah (2019), Zakia et al (2019), Nalarreason et al (2019), Purnama (2017), Astari dan Suryanawa (2017), Sihaloho dan Sitanggang (2016), Amelia dan Hernawati (2016) yang menyatakan ukuran perusahaan berpengaruh positif dan signifikan terhadap Manajemen laba. Tujuan dari adanya Manajemen laba ini untuk menghindari biaya politis, semakin besar ukuran sebuah perusahaan, maka biaya politis yang dikeluarkan juga akan semakin besar sejalan dengan ketatnya regulasi pemerintah dalam hal laba. Praktik Manajemen laba dijalankan dengan cara memindahkan laba periode saat ini ke periode selanjutnya, maka laba periode saat ini tidak terlalu tinggi.

\subsubsection{Pengaruh Leverage $\left(\mathrm{X}_{2}\right)$ Terhadap Manajemen Laba (Y)}

Berdasarkan table 1 menunjukan besarnya t hitung sebesar 0.206, dengan tingkat signifikansi sebesar 0.838 (> 0.05) maka $\mathrm{H}_{0}$ diterima $\mathrm{H}_{\mathrm{i}}$ ditolak yang berarti leverage tidak berpengaruh signifikan terhadap Manajemen laba. Hal ini membuktikan bahwa tingkat leverage perusahaan BUMN yang terdaftar dalam Bursa Efek Indonesia tidak mempengaruhi terjadinya praktik Manajemen laba. 
Berdasarkan data peneltian rata-rata perusahaan BUMN yang terdaftar dalam Bursa Efek Indonesia memiliki tingkat leverage yang aman dan mampu untuk membayar hutang yang digunakan untuk membiayai aset perusahaan, sehingga Manajer (agent) tidak tertarik atau tidak termotivasi untuk melakukan praktek Manajemen laba.

Hasil penelitian ini sejalan dengan penelitian yang dilakukan oleh Zakia et al (2019), Maruli et al (2018), Purnama (2017), Susanto dan Majid (2017), Tala dan Karamoy (2017), Dimarcia dan Krisnadewi (2016), Mariana et al, (2016), Gunawan et al (2015), Veronica (2015), Wiyadi et al (2015), Ulya dan Khairunnisa (2015), bahwa leverage tidak berpengaruh signifikan terhadap Manajemen laba. Berdasarkan teori keagenan yang dinyatakan oleh Jensen dan Meckling (1976), perusahaan dengan proporsi utang yang tinggi dalam struktur modal akan memiliki pengendalian biaya yang tinggi. Pengendalian biaya muncul karena kepentingan pemegang saham untuk memantau kegiatan Manajemen, terutama untuk mengelola dana dan fasilitas yang disediakan oleh pemegang saham untuk menjalankan perusahaan. Oleh karena itu, perusahaan yang memiliki leverage tinggi, mereka memiliki kewajiban lebih untuk memenuhi kebutuhan informasi yang memadai bagi pemegang saham dan kreditor.

Hasil penelitian ini berbeda dengan debt equity hypothesis yang dipaparkan oleh Watt dan Zimmerman (1990). Debt equity hypothesis berasumsi bahwa semakin tinggi rasio utang atau ekuitas suatu perusahaan ekuivalen dengan semakin dekatnya perusahaan terhadap kendala-kendala dalam perjanjian dan terjadinya cost kemacetan teknis, semakin mungkin Manager untuk menggunakan metodemetode akuntansi yang meningkatkan laba. Debt equity hypothesis Watt dan Zimmerman dibuktikan oleh penelitian Apriyani et al (2019), Fandriani dan Tunjung (2019), Nalarreason et al (2019), Agustia dan Suryani (2018), Minarsy et al (2018), Astari dan Suryanawa (2017), Wardani dan Isbela (2017), Sihaloho dan Sitanggang (2016), Wiasa Putri dan Widanaputra (2015), Agustia (2013), Napitupulu (2012) menyatakan leverage mempunyai pengaruh positif dan signifikan terhadap Manajemen laba. Perusahaan dengan tingkat leverage yang tinggi akibat besarnya total hutang terhadap total aktiva akan menghadapi resiko 
default yang tinggi yaitu perusahaan terancam tidak mampu memenuhi kewajibannya. Tindakan Manajemen laba dapat dijadikan sebagai mekanisme untuk menghindarkan default tersebut. Pemenuhan kewajiban harus tetap dilakukan dan dapat dihindarkan dengan Manajemen laba.

\subsubsection{Pengaruh Profitabilitas ( $\left.X_{3}\right)$ Terhadap Manajemen Laba (Y)}

Berdasarkan tabel 1 menunjukan besarnya t hitung sebesar 1.497, dengan tingkat signifikansi sebesar 0.143 (> 0.05) maka $\mathrm{H}_{0}$ diterima $\mathrm{H}_{\mathrm{i}}$ ditolak yang berarti profitabilitas tidak berpengaruh signifikan Manajemen laba. Hal ini membuktikan bahwa tingkat profitabilitas perusahaan BUMN yang terdaftar dalam Bursa Efek Indonesia tidak mempengaruhi terjadinya praktik Manajemen laba. Berdasarkan Kriteria Penilaian Kinerja Unggul (KPKU) yang dikeluarkan oleh Kementerian BUMN, bahwa penilaian kinerja perusahaan BUMN tidak hanya dari aspek keuangan saja, namun juga dari aspek non keuangan. Hal ini menyebabkan Manajer (agent) tidak tertarik atau tidak termotivasi untuk melakukan praktek Manajemen laba dengan meningkatkan atau mengurangi tingkat profitabilitas perusahaan.

Penelitian ini sejalan dengan penelitian yang dilakukan oleh Fandriani dan Tunjung (2019), Agustia dan Suryani (2018), Wardani dan Isbela (2017), Amelia dan Hernawati (2016), Yusrilandari et al (2016), Wiyadi et al (2015), dan Gunawan et al (2015) bahwa variabel profitabilitas tidak berpengaruh signifikan terhadap Manajemen laba. Hal ini menunjukan bahwa semakin tinggi atau rendahnya profitabilitas yang diperoleh oleh suatu perusahaan tidak akan mempengaruhi tingkat Manajemen laba perusahaan. Profitabilitas yang semakin meningkat menunjukkan kinerja perusahaan yang baik dan para pemegang saham akan menerima keuntungan yang semakin meningkat, selain itu Manajer juga mendapatkan keuntungan sehingga dia tidak akan melakukan tindakan Manajemen laba.

Hasil penelitian ini berbeda dengan bonus plan hypothesis yang dipaparkan oleh Watt dan Zimmerman (1990). Bonus plan hypothesis berasumsi bahwa terdapat kecenderungan bagi manajemen untuk menggunakan metode-metode akuntansi yang meningkatkan laba apabila perusahaan menetapkan skema kompensasi bonus yang didasarkan pada profit. Bonus plan hypothesis Watt dan 
Zimmerman dibuktikan oleh penelitian Riska Astari dan Suputra (2019), Zakia et al (2019), Minarsy et al (2018), Maruli et al (2018), Lestari (2018), Purnama (2017), Astari dan Suryanawa (2017), Tala dan Karamoy (2017), Ulya dan Khairunnisa (2015), Noviyanti (2014), Napitupulu (2012) menyatakan bahwa profitabilitas berpengaruh positif dan signifikan terhadap Manajemen laba, hal ini menunjukkan bahwa semakin tinggi profitabilitas maka semakin tinggi Manajemen laba. Profitabilitas menunjukkan kemampuan Manajer dalam menghasilkan laba dengan memanfaatkan aset yang digunakan dalam kegiatan operasi. Profitabilitas dapat mempegaruhi Manajer untuk melakukan Manajemen laba, karena jika profitabilitas yang didapat perusahaan rendah, umumnya Manajer akan melakukan tindakan Manajemen laba untuk menyelamatkan kinerjanya di mata pemegang saham. Hal ini berkaitan erat dengan usaha Manajer untuk menampilkan performa terbaik dari perusahaan yang dipimpinnya.

\subsubsection{Pengaruh Latar Belakang Pendidikan Direktur Utama $\left(\mathrm{X}_{4}\right)$ Terhadap Manajemen Laba (Y)}

Berdasarkan tabel 1 menunjukan besarnya t hitung sebesar 1.814, dengan tingkat signifikansi sebesar $0.078(>0.05)$ maka $\mathrm{H}_{0}$ diterima $\mathrm{H}_{\mathrm{i}}$ ditolak yang berarti latar belakang pendidikan direktur utama tidak berpengaruh signifikan terhadap Manajemen laba. Hal ini membuktikan bahwa latar belakang pendidikan direktur utama perusahaan BUMN yang terdaftar dalam Bursa Efek Indonesia tidak mempengaruhi terjadinya praktik Manajemen laba. Penelitian ini sejalan dengan penelitian yang dilakukan oleh $\mathrm{Hu}$ et al (2017) dan $\mathrm{Hu}$ et al (2013), bahwa direktur utama yang memiliki latar belakang pendidikan akuntansi dan keuangan tidak berpengaruh terhadap Manajemen laba. Direktur utama yang memiliki latar belakang pendidikan akuntansi dan keuangan cenderung menggunakan prinsip konservatisme dalam pelaporan keuangan, tidak bertindak agresif, dan memiliki tingkat akurasi yang tinggi.

Hasil penelitian ini berbeda dengan penelitian yang dilakukan oleh Isidro dan Gonçalves (2011) dan Chiang et al (2016), yang menyatakan bahwa Chairman Of the Boards (COBs) dengan latar belakang pendidikan manajemen dan keuangan berpengaruh signifikan negatif terhadap Manajemen laba, Chairman Of the Boards 
(COBs) dengan latar belakang pendidikan akuntansi berpengaruh signifikan positif terhadap Manajemen laba. Penelitian Gounopoulos dan Pham (2018) menyatakan bahwa direktur utama yang memiliki keahlian dalam bidang akuntansi dan keuangan berpengaruh signifikan negatif terhadap Manajemen laba. Hal ini menunjukan bahwa direktur utama yang memiliki keahlian dalam bidang akuntansi dan keuangan akan lebih berhati-hati (konservatis) dalam membuat laporan laba perusahaan agar cenderung stabil sehingga akan menarik Investor.

\subsubsection{Pengaruh Direktur Utama Yang Akan Mengakhiri Masa Jabatannya (X) Terhadap Manajemen Laba (Y)}

Berdasarkan tabel 1 menunjukan besarnya t hitung sebesar -0.725 , dengan tingkat signifikansi sebesar 0.473 (> 0.05) maka $\mathrm{H}_{0}$ diterima $\mathrm{H}_{\mathrm{i}}$ ditolak yang berarti direktur utama yang akan mengakhiri masa jabatannya tidak berpengaruh signifikan terhadap Manajemen laba. Hal ini membuktikan bahwa direktur utama yang akan mengakhiri masa jabatannya pada perusahaan BUMN yang terdaftar dalam Bursa Efek Indonesia tidak mempengaruhi terjadinya praktik Manajemen laba. Berdasarkan data penelitian, semua pergantian direktur utama pada perusahaan BUMN yang terdaftar dalam Bursa Efek Indonesia terjadi sebelum berakhirnya periode (lima tahun) jabatan, sehingga direktur utama tidak memiliki cukup waktu untuk melakukan Manajemen laba.

Penelitian ini sejalan dengan penelitian yang dilakukan oleh Murphy dan Zimmerman (1993), Vernando dan Rakhman (2018), bahwa direktur utama yang akan mengakhiri masa jabatannya tidak berpegaruh terhadap Manajemen laba, hal ini dikarenakan direktur utama tidak memiliki cukup waktu untuk mengurangi pengeluaran diskresioner untuk meningkatkan laba. Direktur utama akan memiliki cukup waktu untuk melakukan Manajemen laba jika direktur utama tersebut mengetahui kapan masa jabatannya berakhir atau pensiun.

Hasil penelitian ini berbeda dengan penelitian yang dilakukan oleh Ali dan Zhang (2015), Patni dan Sujana (2016), Dewi dan Rasmini (2018) menyatakan bahwa direktur utama yang akan mengakhiri masa jabatannya di suatu perusahaan berpengaruh positif dan signifikan terhadap Manajemen laba. Hal ini menunjukan direktur utama yang akan mengakhiri masa jabatannya di suatu perusahaan 
memiliki dorongan untuk memanipulasi laba guna memperoleh bonus yang lebih tinggi di masa akhir jabatannya. Direktur utama juga akan ingin menunjukkan kinerja terbaiknya dengan harapan akan menaikan reputasi dan citra mereka, sehingga meningkatkan kemungkinan direktur utama tersebut dipilih kembali untuk periode jabatan selanjutnya.

\section{Kesimpulan dan Saran}

\subsection{Kesimpulan}

Berdasarkan hasil analisis dan pembahasan, maka dapat disimpulkan sebagai berikut:

1. Ukuran perusahaan BUMN yang terdaftar dalam Bursa Efek Indonesia tahun 2017 - 2019 tidak berpengaruh terhadap Manajemen laba.

2. Leverage pada perusahaan BUMN yang terdaftar dalam Bursa Efek Indonesia tahun 2017 - 2019 tidak berpengaruh terhadap Manajemen laba.

3. Profitabilitas pada perusahaan BUMN yang terdaftar dalam Bursa Efek Indonesia tahun 2017 - 2019 tidak berpengaruh terhadap Manajemen laba.

4. Latar belakang pendidikan direktur utama pada perusahaan BUMN yang terdaftar dalam Bursa Efek Indonesia tahun 2017 - 2019 tidak berpengaruh terhadap Manajemen laba.

5. Direktur utama yang akan mengakhiri masa jabatannya pada perusahaan BUMN yang terdaftar dalam Bursa Efek Indonesia tahun 2017 - 2019 tidak berpengaruh terhadap Manajemen laba.

\subsection{Keterbatasan}

Penelitian ini memiliki keterbatasan antara lain sebagai berikut:

1. Sampel yang digunakan pada penelitian ini hanya terbatas pada perusahaan BUMN yang terdaftar di Bursa Efek Indonesia tahun 2017 - 2019 yang mempublikasikan laporan keuangan tahunan audited sampai dengan tanggal 30 April 2020. Keterbatasan pada sampel perusahaan yang diteliti dalam penelitian ini menyebabkan tujuan penelitian tidak dapat tercermin secara keseluruhan pada perusahaan BUMN yang terdaftar di Bursa Efek Indonesia (BEI) dan tidak dapat digeneralisasikan pada BUMN yang tidak terdaftar di Bursa Efek Indionesia (BEI). 
2. Penelitian ini hanya menggunakan proksi debt ratio untuk mengukur leverage, proksi Log natural (LN) total asset untuk mengukur ukuran perusahaan dan proksi Return on Asset (ROA) untuk mengukur profitabilitas, sementara masih ada proksi lain yang bisa digunakan untuk mengukur variabel-variabel tersebut.

\subsection{Saran}

Berdasarkan kesimpulan dan keterbatasan penelitian ini, peneliti memberikan beberapa saran antara lain sebagai berikut:

1. Penelitian ini hanya terdiri dari 5 (lima) variabel independen, maka sangat disarankan bagi penelitian selanjutnya agar dapat menambahkan atau menganti dengan variabel-variabel independen yang lain, seperti penerapan Good Corporate Governance (GCG), penyajian kembali laporan keuangan (restatement), pajak tangguhan, kualitas audit, persentase saham publik dan umur perusahaan.

2. Berdasarkan keterbatasan sampel yang digunakan pada penelitian ini, maka sangat disarankan bagi penelitian selanjutnya agar menambahkan periode tahun penelitian. Penelitian juga dapat dilakukan pada objek dan lokasi penelitian lain yang tidak terbatas pada perusahaan BUMN yang terdaftar di Bursa Efek Indonesia.

3. Peneliti selanjutnya dapat menggunakan proksi yang berbeda untuk mengukur leverage seperti proksi Debt Equity Ratio (DER), proksi total penjualan atau nilai pasar saham untuk mengukur ukuran perusahaan dan proksi Return on Equity (ROE) atau Return on Investment (ROI) untuk mengukur profitabilitas untuk mengetahui perbedaan hasil yang diperoleh dengan menggunakan proksi yang berbeda.

\section{DAFTAR PUSTAKA}

Agustia, D. (2013). Pengaruh Faktor Good Corporate Governance, Free Cash Flow, dan Leverage Terhadap Manajemen Laba. Jurnal Akuntansi Dan Keuangan, 15(1), 27-42.

Agustia, P. Y., \& Suryani, E. (2018). Pengaruh Ukuran Perusahaan, Umur Perusahaan, Leverage, Dan Profitabilitas Terhadap Manajemen Laba (Studi 
Pada Perusahaan Pertambangan yang Terdaftar di Bursa Efek Indonesia Periode 2014-2016). Jurnal Aset (Akuntansi Riset), 10(1), 63-74.

Ali, A., \& Zhang, W. (2015). CEO tenure and earnings management. Journal of Accounting and Economics, 59(1), 60-79.

Amelia, W., \& Hernawati, E. (2016). Pengaruh Komisaris Independen, Ukuran Perusahaan, dan Profitabilitas terhadap Manajemen Laba. NeO Bis, 10(1), 62-77.

Apriyani, Ika, S. R., \& Sarnowo, H. (2019). Pengaruh koneksi politik dan corporate governance. ISEI Economic Review, 2(1), 8-15.

Arthawan, P. T., \& Wirasedana, W. P. (2018). Pengaruh Kepemilikan Manajerial, Kebijakan Utang Dan Ukuran Perusahaan Terhadap Manajemen Laba. EJurnal Akuntansi, 22,(1), 1-29.

Asitalia, F., \& Trisnawati, I. (2017). Pengaruh Good Corporate Governance Dan Leverage Terhadap Manajemen Laba. Jurnal Bisnis Dan Akuntansi, 19(2), 109-119.

Astari, M. R, A. A., \& Suryanawa, I. K. (2017). Faktor-Faktor Yang Mempengaruhi Manajemen Laba. E-Jurnal Akuntansi, 20(1), 290-319.

Ayem, S., \& Arifah, P. H. N. (2019). Pengaruh Ukuran Perusahaan, Konvergensi IFRS, Dan Perencanaan Pajak Terhadap Manajemen Laba. Jurnal Akuntansi Pajak Dewantara, 1(2), 171-180.

Chiang, H., Lin, S., He, L., \& Sung, Y. (2016). Professional education background and earnings management of chairmen and senior managers. The International Journal of Business and Finance Research, 10(2), 91-108.

Dewi, A. K., \& Rasmini, N. K. (2018). Perbedaan Earnings Management pada Pergantian Chief Executive Officer pada Perusahaan Manufaktur yang Terdaftar di BEI. E-Jurnal Akuntansi Universitas Udayana, 23(2), 1442-1469.

Dimarcia, N., \& Krisnadewi, K. (2016). Pengaruh Diversifikasi Operasi, Leverage Dan Kepemilikan Manajerial Pada Manajemen Laba. E-Jurnal Akuntansi, 15(3), 2324-2351.

Fandriani, V., \& Tunjung, H. (2019). Pengaruh Surplus Arus Kas Bebas, Ukuran Perusahaan, Leverage, Dan Kualitas Audit Terhadap Manajemen Laba. Diponegoro Journal of Accounting, 7(4), 505-514. 
Gounopoulos, D., \& Pham, H. (2018). Financial Expert CEOs and Earnings Management Around Initial Public Offerings. International Journal of Accounting, 53(2), 102-117.

Gunawan, I. K., Darmawan, N. A. S., \& Purnamawati, I. G. A. (2015). Pengaruh Ukuran Perusahaan, Profitabilitas, dan Leverage Terhadap Manajemen Laba. Jurnal Akuntansi Program S1 Universitas Pendidikan Ganesha, 03(1).

Healy, P. M., \& Wahlen, J. M. (1999). Healy 1999. Accounting Horizons, 13(4), 365-383.

Hu, N., Huang, R., Li, X., \& Liu, L. (2017). The impact of CEOs' accounting backgrounds on earnings management and conservatism. Journal of Centrum Cathedra, 10(1), 4-24.

Hu, N., Liu, L., \& Miller, W. (2013). The Path to Reporting Economic Reality Why all CEOs Should Have Accounting Degrees. Journal of Management Policy and Practice, 14(2), 11-18.

Isidro, H., \& Gonçalves, L. (2011). Earnings management and CEO characteristics in Portuguese firms. Corporate Ownership and Control, 9(1 A), 86-95.

Jensen, M. C., \& Meckling, W. H. (1976). Theory of The Firm: Managerial Behavior, Agency Cost and Ownership Structure. Journal of Financial Economics, 3, 305-360.

Kasmir. (2016). Analisis Laporan Keuangan (1st ed.). Raja Grafindo Persada.

Larasati, R. W. (2015). Analisis Faktor-Faktor Yang Mempengaruhi Motivasi Earnings Management Pada Perusahaan Lq-45 Yang Terdaftar Di Bursa Efek Indonesia (Bei) Tahun 2009-2013. Jurnal Akuntansi Akunesa, 3(2), 1-26.

Mariana, A., Susilawati, A. E., \& Purwanto, N. (2016). Pengaruh Good Corporate Governance, Leverage, Dan Ukuran Perusahaan Terhadap Manajemen Laba Perbankan Yang Terdaftar Di Bei. Journal Riset Mahasiswa Akuntansi, $X X($ April 2016), 1-17.

Maruli, S., Afrizal, \& Herawaty, N. (2018). Perbandingan pengaruh free cash flow, profitabilitas dan leverage terhadap manajemen laba pada perusahaan properti, makanan dan minuman yang terdaftar di bursa efek indonesia. JAWARA: Jurnal Wawasan dan Riset Akuntansi, 6(1), 1-17.

Minarsy, R. A., Munthe, I. L. S., \& Ratih, A. E. (2018). Pengaruh Return On Asset (ROA), Dewan Direksi, Komisaris Independen, Komite Audit, Ukuran Perusahaan dan Leverage Terhadap Manajemen Laba Pada Perusahaan 
Manufaktur Sektor Industri Dasar dan Kimia yang Listing di BEI Tahun 20132016. Repository Universitas Maritim Raja Ali Haji.

Murhadi, W. R. (2013). Analisis Laporan Keuangan, Proyeksi dan Valuasi Saham (1st ed.). Salemba Empat.

Murphy, K. J., \& Zimmerman, J. L. (1993). Financial performance surrounding CEO turnover. Journal of Accounting and Economics, 16(1-3), 273-315.

Nalarreason, K. M., T, S., \& Mardiati, E. (2019). Impact of Leverage and Firm Size on Earnings Management in Indonesia. International Journal of Multicultural and Multireligious Understanding, 6(1), 19-24.

Napitupulu, R. (2012). Faktor-Faktor Yang Mempengaruhi Manajemen Laba Pada Perusahaan Manufaktur Yang Terdaftar Di Bursa Efek Indonesia. Jurnal Bisnis Dan Akuntansi, 4(2a), 61-78.

Noviyanti, E. P. (2014). Analisis Pengaruh Mekanisme Good Corporate Governance, Profitabilitas Dan Leverage Terhadap Praktek Manajemen Laba (Earning Management). Sekolah Tinggi Ilmu Ekonomi Perbanas. Surabaya.

Patni, T. N. D., \& Sujana, I. K. (2016). Manajemen Laba Serta Respon Pasar Yang Terjadi Pada Event Pergantian CEO. E-Jurnal Akuntansi Universitas Udayana, 16(3), 1857-1884.

Prihartono, N. C. L. (2018). Pengaruh Good Corporate Governance, Ukuran Perusahaan, Leverage dan Financial Distress terhadap Manajemen Laba (Studi Empiris pada Perusahaan BUMN yang Terdaftar di Bursa Efek Indonesia tahun 2012-2016). Universitas Islam Indonesia.Yogyakarta.

Puji Lestari, F. A. (2018). Pengaruh Profitabilitas dan Beban Pajak Tangguhan terhadap Manajemen Laba. Sosio E-Kons, 10(3), 270-278.

Purnama, D. (2017). Pengaruh Profitabilitas, Leverage, Ukuran Perusahaan, Kepemilikan Institusional Dan Kepemilikan Manajerial Terhadap Manajemen Laba. Jurnal Riset Keuangan Dan Akuntansi, 3(1), 1-14.

Rice. (2016). Pengaruh Faktor Keuangan terhadap Manajemen Laba dengan Corporate Governance sebagai Variabel Moderating. Jurnal Wira Ekonomi Mikroskil, 6(April), 55-72.

Riska Astari, N. K., \& Suputra, I. D. . D. (2019). Pengaruh Ukuran Perusahaan, Kepemilikan Manajerial, dan Kinerja Keuangan Pada Manajemen Laba. EJurnal Akuntansi Universitas Udayana, 26(3), 1938-1968. 
Santi, D. K., \& Wardani, D. K. (2018). Pengaruh Tax Planning, Ukuran Perusahaan, Corporate Social Responsibility (CSR) Terhadap Manajemen Laba. Jurnal Akuntansi, 6(1), 11-24.

Sari, S. R., \& Asyik, N. F. (2013). Pengaruh Leverage Dan Mekanisme Good Corporate Governance Terhadap Manajemen Laba. Jurnal Ilmu Dan Riset Akuntansi, 2(6).

Scott, W. R. (2011). Financial Accounting Theory (6th ed.). Person Prentice Hall.

Setiawati, L., \& Na'im, A. (2000). Manajemen Laba. Jurnal Ekonomi Dan Bisnis Indonesia, 15(4), 424-441.

Sihaloho, K. V., \& Sitanggang, A. (2016). Pengaruh Asimetri Informasi, Leverage, dan Ukuran Perusahaan Terhadap Praktik Manajemen Laba (Studi Pada Perusahaan Manufaktur yang Terdaftar di Bursa Efek Indonesia). Jrak, 2(2), 173-190.

Susanto, I. R., \& Majid, J. (2017). Faktor-Faktor Yang Mempengaruhi Manajemen Laba Pada Perusahaan Manufaktur Di Bei. Jurnal Ilmiah Akuntansi Peradaban, 3(2), 65-83.

Tala, O., \& Karamoy, H. (2017). Analisis Profitabilitas Dan Leverage Terhadap Manajemen Laba Pada Perusahaan Manufaktur Di Bursa Efek Indonesia. Accountability, 6(1), 57-64.

Ulya, N., \& Khairunnisa. (2015). Pengaruh Ukuran Perusahaan , Profitabilitas , Financial Leverage Dan Kualitas Audit Terhadap Praktik Manajemen Laba. E-Prociding of Management, 2(1), 324-331.

Vernando, A., \& Rakhman, F. (2018). Masa Kerja Ceo Dan Manajemen Laba (Ceo Tenure and Earnigs Management). Jurnal Akuntansi Dan Keuangan Indonesia, 15(2), 202-216.

Veronica, A. (2015). The Influence of Leverage and Its Size on the Earnings Management. Research Journal of Finance and Accounting, 6(8), 159-167.

Wardani, D. K., \& Isbela, P. D. (2017). Pengaruh strategi bisnis dan Karakteristik Perusahaan Terhadap Manajemen Laba. Jurnal Riset Akuntansi Dan Keuangan Fakultas Bisnis UKDW, 13(2), 91-106.

Watts, R., \& Zimmerman, J. (1990). Positive Accounting Theory: A Ten Year Perspective. Accounting Review, 65, 131-156. 
Wiasa Putri, Y., \& Widanaputra, A. (2015). Pengaruh Asimetri Informasi, Leverage Dan Pergantian Chief Executive Officer Pada Praktik Manajemen Laba. EJurnal Akuntansi, 11(3), 756-770.

Wiyadi, Trisnawati, R., Sasongko, N., \& Fauzi, I. (2015). The Effect of Information Assymmetry, Firm Size, Leverage, Profitability and Employee Stock Ownership on Earnings Management with Accrual Model. International Journal of Business and Management and Law, 8(2), 21-30.

Yusrilandari, L. P., Hapsari, D. W., \& Mahardika, D. P. K. (2016). Pengaruh Profitabilitas, Kepemilikan Manajerial, Dan Ukuran Perusahaan Terhadap Manajemen Laba(Studi Kasus Pada Perusahaan Sektor Industri Barang Konsumsi Yang Terdaftar Di Bursa Efek Indonesia Periode 2012-2015). EProceeding of Management, 3(3), 3159-3167.

Zain, A. (2015). Manajemen Laba Dalam Praktik Manajemen Impresi Pada Perusahaan BUMN Yang Terdaftar Di Bei Periode 2012-2014. Akrual: Jurnal Akuntansi, 6(2), 115-126.

Zakia, V., Diana, N., \& Mawardi, M. C. (2019). Pengaruh Kepemilikan Manajerial, Kepemilikan Institusional, Ukuran Perusahaan, Leverage, Profitabilitas, Pertumbuhan Penjualan Terhadap Manajemen Laba Dengan Good Corporate Governance Sebagai Variabel Moderating. E-Jounal Riset Akuntansi . Fakultas Ekonomi Dan Bisnis Universitas Islam Malang, Vol.08(04), 26-39. 